\title{
The Distortion of Public Perception towards the Quick Count Results in 2019 Elections
}

\author{
Zamhasari Zamhasari ${ }^{1}$, Dhea Elsa Novita ${ }^{2}$, Elhanna Rizky Juliani ${ }^{3}$, Sriatin \\ Sriatin 4 \\ ${ }^{1}$ Universitas Abdurrab \\ ${ }^{2,3,4}$ Universitas Lancang Kuning \\ zamhasari@univrab.ac.id
}

\begin{abstract}
This article discusses public beliefs regarding the results of quick count in 2019 elections. There was a problem of differences in public perception of the quick count results which caused various polemics in the community. This phenomenon occurs when people disagree with the quick count results, so some accuse falsehood with survey institutions and the media. The theory explained that there are still people who have not been able to distinguish between original news or facts and hoax. Through a media framing analysis approach, this study explains the impact of divisions among the people who perceive very different quick count results. Based on the facts or data, voter distortion in the election against the quick count results is caused by the lack of political education and civic culture for election participants in Indonesia.
\end{abstract}

Keywords: Distortion; election; quick count; public perception

\section{Introduction}

In a narrow sense, public perception is how someone looks at their social environment. While that's how people view and interpret stimuli and information in a broad sense of public perception. In order to understand information it is important to try to recognize others and also to search for exact data and facts to ensure that the perception of others is not distorted. Since perception is less accurate, weaknesses in data selection are necessary. The society would provoked easily by the news that has no basis in facts and clear sources (Anggoro, 2016). If the society is not careful when choosing accurate information and data, it can distort them.

The participation of citizens in voting rights in regional elections is one of indicators in the success of the elections towards a consolidated and quality local democracy (Yandra, 2017). The distortion of perception that occurs certainly causes chaos and damages the process of public communication, such as the public situation in Indonesia after the 2019 election. The chaos begins with the distortion, through quick count and justification, from a figure of the presidential candidate for election fraud.

Regarding the quick count problem, 40 survey institutions have received permission from the KPU to implement the quick count. The publication of the quick counts results with different results, however, raises polemic of the victory claims between candidate pairs caused by different samples. The quick count results of the 2019 presidential election can be seen from the table below: 


\section{Table 1}

\section{Survey institution that won Jokowi-Ma'ruf candidate pair}

\begin{tabular}{lcc}
\hline Survey Institute & Jokowi - Ma'ruf & Prabowo - Sandi \\
\hline $\begin{array}{l}\text { INDO BAROMETER (Berometer Perilaku } \\
\text { Masyarakat Indonesia) }\end{array}$ & $54.35 \%$ & $45.65 \%$ \\
$\begin{array}{l}\text { Lembaga Survey Indonesia } \\
\text { Lembaga Survey Kedai Kopi (KELOMPOK }\end{array}$ & $55.71 \%$ & $44.29 \%$ \\
$\begin{array}{l}\text { DISKUSI DAN KAJIAN OPINI PUBLIK } \\
\text { INDONESIA) }\end{array}$ & $54.74 \%$ & $45.25 \%$ \\
$\begin{array}{l}\text { Poltracking Indonesia (Akurat, Kredibel, } \\
\text { Kompeten) }\end{array}$ & $54.98 \%$ & $45.02 \%$ \\
$\begin{array}{l}\text { Populi Center (PUBLIC OPINION \& POLICY } \\
\text { RESEARCH) }\end{array}$ & $54.01 \%$ & $45.99 \%$ \\
\hline
\end{tabular}

Source: Republika.co.id

According to the table, candidate pair number 01 won the quick count results, but this is also a debate, the result of the quick count caused the perception. The problem is each candidate pair (paslon) has its vote calculation results and has different votes obtained from the survey institutions of each candidate pair. Besides, the trigger is that each them (paslon) claims its victory, whose clarity is uncertain.

Data on institutions that won Prabowo are found in the survey agencies. If traced the spread of hoax news about the existence of fraud against camp 01, it is used by irresponsible people who want to make a profit, thus making the community more chaotic.

Thus the public should learn in detail about all the information that is true and not be easily influenced by news that is not yet certain of its truth.

\section{Theoretical Perspectives}

\subsection{Research Method}

This research used a framing method with information collection techniques through articles or literature study. The reason for choosing this approach is the researcher wants to understand, analyze and explain variations in public perceptions. The approach used in this research is the literature study, with a descriptive type by looking for patterns of relationship between political phenomena and explaining them. Nazir (1988) said that library research is a data collection technique by conducting a review of various books, literature, notes, and several reports relating to the problem to be solved.

All data will be analyzed using the framing method through interpretation. This process used theories and information from news and articles. Furthermore, the process of reducing the analysis results can be structured and to be accounted scientifically and even become new findings in developing the theories.

One of the data compared using the framing method is to compare the quick count results on Metro TV led to a Prabowo-Sandi victory which in the end only mentioned a technical error with the news on CNN Indonesia which stated that Jokowi-Ma'ruf won in quick count result. 


\section{Result and Discussion}

3.1 Quick Count

Quick count is suitable for use in developing countres that have large areas, which require days or even weeks in voting count (Susilowati, 2019). The quick count process was released on 17 April 2019 at $15: 00$ by various institutions. From the sources obtained, 40 survey institutions conduct quick counts, but the authors only describe some of the institutions and the results of the quick count. Following are the results of the 2019 presidential election quick count from several survey institutions:

\begin{tabular}{|c|c|c|c|}
\hline \multirow{2}{*}{ Source/Institution } & \multicolumn{2}{|c|}{ Candidates } & \multirow{2}{*}{ Sample entry } \\
\hline & $\underline{\text { Jokowi-Amin }}$ & Prabowo-Sandi & \\
\hline $\begin{array}{l}\text { Saiful Mujani Research and Consulting } \\
\text { [40] }\end{array}$ & $54,85 \%$ & $45,15 \%$ & $97,72 \%$ \\
\hline Indikator Politik Indonesia & $53.91 \%$ & $46.09 \%$ & $95.70 \%$ \\
\hline Poltracking & $54.98 \%$ & $45.02 \%$ & $100.0 \%$ \\
\hline Populi Center & $54.00 \%$ & $46.00 \%$ & $98.15 \%$ \\
\hline LSI Denny JA & $55.71 \%$ & $44.29 \%$ & $100.0 \%$ \\
\hline Litbang Kompas & $54.43 \%$ & $45.57 \%$ & $99.95 \%$ \\
\hline Indo Barometer & $54.35 \%$ & $45.65 \%$ & $99.83 \%$ \\
\hline KedaiKOPI & $54.20 \%$ & $45.80 \%$ & $90.25 \%$ \\
\hline Median & $54.52 \%$ & $45.68 \%$ & $98.02 \%$ \\
\hline CSIS-Cyrus & $55.60 \%$ & $44.40 \%$ & $99.99 \%$ \\
\hline Charta Politika & $54.34 \%$ & $45.65 \%$ & $99.83 \%$ \\
\hline Konsep Indonesia [41] & $54.03 \%$ & $45.97 \%$ & $99.80 \%$ \\
\hline Voxpol Center[42] & $54.55 \%$ & $45.45 \%$ & $100.0 \%$ \\
\hline Cyrus Network & $56,04 \%$ & $38,01 \%$ & $94,05 \%$ \\
\hline Media Survey Nasional & $46,19 \%$ & $45,15 \%$ & $91,34 \%$ \\
\hline Indodata & $54,08 \%$ & $32,05 \%$ & $86,13 \%$ \\
\hline Celebes Research Center & $56,01 \%$ & $31,07 \%$ & $87,08 \%$ \\
\hline Indomatrik & $47,97 \%$ & $44,04 \%$ & $92,01 \%$ \\
\hline
\end{tabular}


From the following table, it can be seen the results of the survey institute who did the quick and average calculation, it was won by Jokowi-Ma'aruf.

However, the problem is several institutions claim Prabowo-Sandi victories so the information circulating becomes ambiguous, unclear and the issues circulating are increasingly heated. Thus the community becomes divided between each supporter.

The following diagram shows the survey results of institutions that won by Prabowo-Sandi:

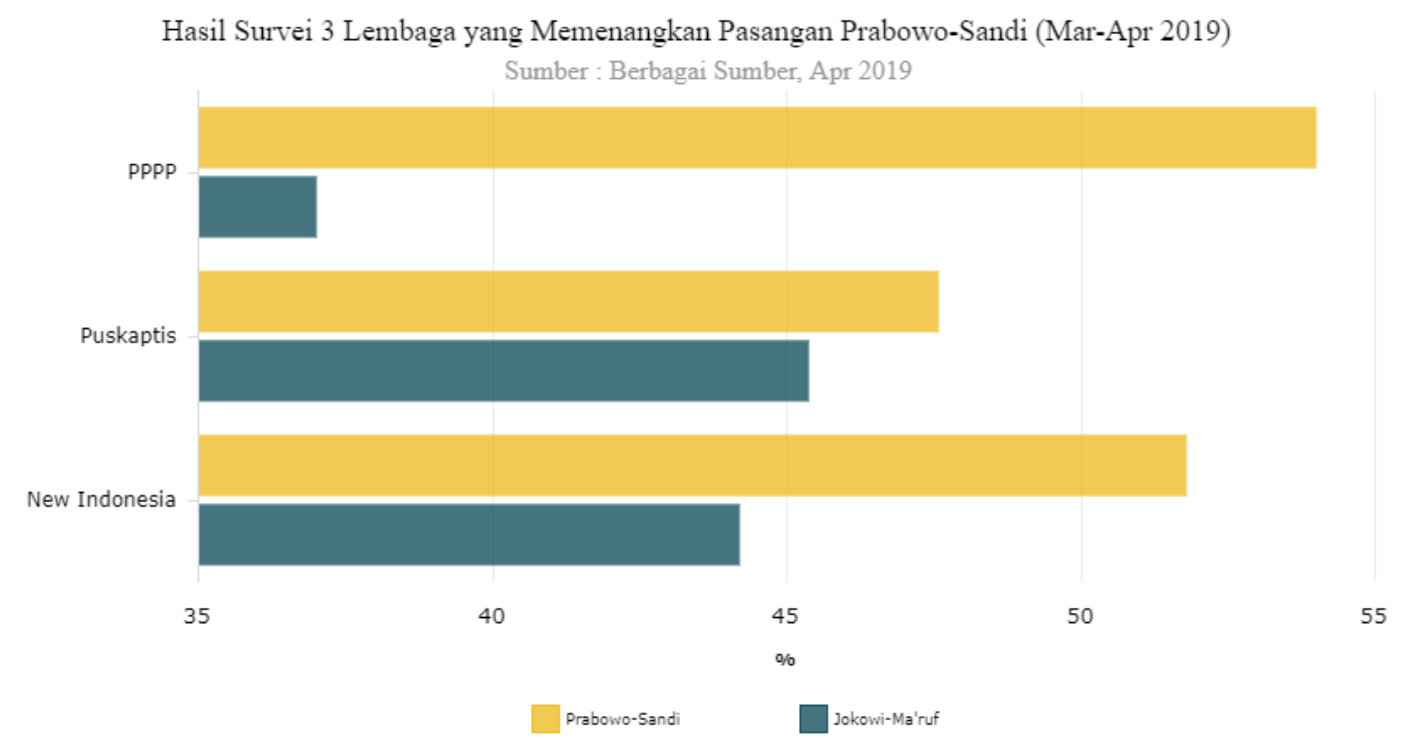

Dkatadata 

If it is seen from the following diagram, the PPPP (Precision Public Policy Polling) survey institute, Puskaptis (Center for Policy Studies and Strategic Development), and New Indonesia won Prabowo-Sandi candidate pair.

But with the victory by number 01 candidate, many citizen seems disbelief, and claim it was only a fraud made by the number 01 candidate. However, as a good citizen, there's no need to assume with the news which is uncertain. It is better to find the truth before it disseminated again, so the information is not ambiguous and overlapping since many citizens are still lay and do not understand about politics, or some understand but are indifferent with issues or news that are circulating. In contrast, information continues to roll whether the truth is happening or still doubtful.

Thus, the media and press have an essential role for politics in Indonesia, especially in elections.

In the Press Law No.40 of 1999, it was stated that the press was a social institution and a vehicle for mass communication. The press carries out journalistic activities and acts as an information media that has educational, entertainment and social control functions. As an information media, the press has the responsibility to disseminate positive information that supports the progress of the community. As an educational medium, the press is responsible for conveying facts objectively and selectively, for balancing the flow of information. As a medium of entertainment, the press is responsible to provide entertainment that is neutral and educational, and as a medium of social control, the press serves to convey and expose adverse events, or circumstances that violate the rules, out of place; that happens in people's lives. It is done solely the community is aware of the events around them, and is alert and can take precautions so that similar incidents do not recur. Also, it will be able to increase public awareness to obey the rules and doing well to others.

In its function as social control, the press contains a democratic meaning which has elements: social participation, namely the participation of the people in government; social responsibility, the government's responsibility to the people; social support, the people's support for the government; and social control, namely oversight of government actions in the community.

We will explain more broadly about press functions in social control media below.

1. The press have functions to implement social control to prevent power abuse, especially in government. It can be in the form of corruption, collusion, nepotism $(\mathrm{KKN})$, or deviations and other positions. Through mass media (read: the influence of social media, the press plays an essential role in improving the situation.

2. The press serve to convey and explain the adverse events that happened in society. These unfortunate events can be in the form of conditions that violate the rules or conditions that are not in place. The function of press as 'delivering bad news' is important, so that people can find solutions to prevent it, or at least be more vigilant; the similar events will be no longer happen. Also, bad news who delivered by the press can increase public awareness in obeying the rules and norms that apply in society.

3. Besides, reporting misappropriation in the government, the press also functions to report the policies that are carried out by the government in actual and factual terms. It needs to be done so that the community can provide support to the 
government, related to the policy (read: political communication). Thus, in addition to facilitating the government in carrying out community development, it will also educate the community and prevent them from looking at the wrong side of the government.

4. The press functions as a bridge between all social parties, providing balanced and actual information. In this case, the press must be neutral. When power abuses are carried out by government officials, such as corruption; the news who is the press done could make people respond to it and move to demand for the improvement situation (read: the role of mass media in moral formation). Conversely, when an improper situation occurs in community, then the number of people who respond to the news will be even more significant; As a result, the government will inevitably consider and respond to the media issue.

5. As social control, the press is expected to play an active role in the government system, both related to government policies and the flow of funds, and others (also read: journalistic position in communication science). So that there is transparency in the government system of society. In this case, the press acts as a watchdog of the public interest, where the press must always defend the interests of the community.

6. Besides the press have an active role in government system, as social control, the press is also responsible for playing an active role in the social system. Both related to public opinion created, as well as the state of society itself so that the press will encourage the creation of an intelligent and prosperous society.

7. The press functions as a tool for social change and community renewal. By doing various news that is considered necessary, the press can educate the public and encourage the formation of public opinion. Thus it will encourage change and renewal in the community itself.

8. In a democratic country like Indonesia (read: the Indonesian communication system), the press functions as a guardian of democracy. To carry out this role, the press is required to do environmental monitoring, actively wherever the press is located. It was stated expressly by the government, by putting it in Press Law No. 40 of 1999.

9. The Press reporting functions as a reward and punishment system for the government and the community. For the government, for example, report about misappropriation of funds or corruption by certain government officials will have a deterrent effect. They will also be more careful in committing corruption, so hopefully, the amount of corruption will be reduced. On the contrary, the value of good news carried out by the government will give a positive response or praise from the public, thus making the relevant officials feel valued and compelled to try to build the State better. For the community, when the goodness in the community is delivered, it will indirectly bring praise to the community concerned. It also encourages other communities to follow the footsteps of the goodness they do. And vice versa, the badness committed by some aspects of the community will lead to reproach, which will be a social punishment for the relevant elements.

The press or media functions to control, criticize, and correct everything related to the government and social system, which are constructive. The constructive intention here is that all press reporting must be 
constructive, and not destructive (order) in society and government. In this case, the press is obliged to exercise control and selection of the published reports and which are essential, which are necessary and appropriate to be disseminated.

\subsection{Framing}

The framing method is one method of media analysis, as well as content analysis and semiotic analysis. In simply stated, Framing is used to frame an event or, in other words, it is to identify the prospect or perspective used by journalists or mass media to select issues and write the news.

Framing is a method of presenting reality in which the truth about an event is not totally denied, but it is subtly deflected, by giving emphasis on certain aspects. Highlighting certain aspects of the issue relates to writing facts. When certain aspects of an event are chosen, how they are written. This is very related to the use of diction or words, sentences, pictures or photographs, and specific images to be displayed to the public.

Framing analysis is used to study the framing of reality (events, individuals, groups) conducted by the mass media. Framing is a construction process, which means that reality is interpreted and reconstructed in specific ways and meanings. As a result, only certain parts are more meaningful, more attention, considered necessary, and more familiar in the minds of the public. In practice, framing analysis is widely used to look at newspaper frames, so it can be seen that each newspaper has its political policy.

By looking at the framing displayed by the survey agency, some institutions won Prabowo-Sandi, and some other institutions won the Jokowi-Ma'ruf. There was an alliance between the two parties that finally issued a different result which was caused by a technical error during data input.

\subsection{Distortion of Public Perception to Quick Count in 2019 Elections}

This year, Indonesia faced a democratic party by holding elections. The democratic party is the presidential and legislative elections. The implementation of the presidential election is also a follow up to the realization of the principles of democracy which incudes guarantees for the principles of individual freedom and equality, especially in political rights (Zuhro, 2019). This democratic party is awaited because it is only held once every 5 years. Every election is held; there are only unique events that occur. There must be a series of issues such as hoax news scattered, mutual claims of victory and so on (Ramadani, 2019). For this year, political parties in Indonesia are very numerous, and the 2019 presidential election will be the first to be held simultaneously with legislative elections. Because democratic parties are being held massively throughout Indonesia, the costs involved are huge. Based on the data obtained, it has been budgeted around Rp. 24,8 trillion, this value has increased by Rp. 700 billion compared to the 2014 election.

In 2019 election, the pair of candidates elected as presidents was Joko Widodo and Ma'ruf Amin, recruitment number 01. The public did not immediately accept the results in the winnings won by the candidate pair 01 . Many public perceptions conflict with the quick count results in the 2019 election. With these different perceptions, some people believe that the results are not real, and some others prefer to believe with the quick count results.

The quick count results obtained in the election are different; this causes much public perception. It is sourced from Republika.co.i 

Jakarta, the Indonesian Public Opinion Survey (Persepsi) assesses the difference of quick count results can cause problems for the democratic process which in the perceived value has shown the maturity of the Indonesian people. The research institute must provide political education to all Indonesian people because researchers include third parties whose job is to teach politics about the community so that there is no public perception that causes significant problems.

According to the perception of differences in the results of fast calculations can damage democracy, negligent parties can exploit differences in results from one institution to another quick count because it becomes a problem if these different results become a reference.

Credibility is the quality, capability, or strength to generate trust. The legitimate general application of the term credibility relates to the testimony of a person or institution during a conference. Testimony must be competent and credible if it is to be accepted as evidence of a contentious issue.

Prabowo Subianto claimed that he won the 2019 Election as President of Indonesia with 62 percent of votes. However, the results were obtained from an internal survey that did a quick count.

Responding to that, the Indonesian Survey Circle (LSI), Denny JA questioned the credibility of the internal survey from Prabowo and the National Winning Agency (BPN).

Prabowo also claimed that several national survey institutions were paying and adopted the assumption that he had lost to Joko Widodo (Jokowi).

Survey institutions that are credible and have received recognition from both the public and from the General Election
Commission (KPU), the stronghold of candidate pair (Paslon) number 02 instead they conduct an internal survey. They considered that the survey institute was no longer neutral. Even worse, there are allegations that survey institutions have been paid by certain groups to favour one candidate pair.

Charta Politika Indonesia's Executive Director, Yunarto Wijaya, said that the internal survey was doubtful about credibility. Moreover, the survey was conducted by those who participated in this election.

\section{Conclusion}

This study found that the credibility of the survey institute still sided with each candidate, thusthe results of the quick count were different. It is because the survey institute did not carry out the institution's commitment independently and was more likely to benefit one of the candidate pairs.

This study advised the government to carry out control and evaluate the functions of survey institutions that are not credible. This is important so survey agencies in Indonesia work by the correct methodologies and techniques in conducting surveys.

\section{References}

Abdi, A. M., Sultan, M. I., \& Hasrullah, H. (2016). Pendapat politisi terhadap kredibilitas lembaga survei tentang elektabilitasnya dalam pemilihan legislatif DPRD Sulsel 2014. KAREBA: Jurnal Ilmu Komunikasi, 3(4), 226-234.

Anggoro, A. D. (2016). Media, Politik dan Kekuasaan (Analisis Framing Model Robert N. Entman tentang pemberitaan hasil pemilihan 
Presiden, 9 Juli 2014 di TV One dan Metro TV). ARISTO, 2(2), 25-52.

Dayanti, D. A. (2019). Konstruksi Media Online Tentang Deklarasi Kemenangan Prabowo Subianto Dalam Pemilihan Presiden 2019 (Analisis Framing pada Pemberitaan di Detik. com dan Merdeka. com periode 17 April-25 April 2019) (Doctoral dissertation, University of Muhammadiyah Malang).

Ramadani, A. L. (2019). Hasil Pemilihan Umum Presiden 2019 Mengubah Etika Berpolitik dan Moral Keutamaan.

Susilowati, I. (2019). Counter-Attack Pasca Penghitungan Suara Pilpres 2019 Menuju Real Count. 'ADALAH, 3(4).

Yandra, A. (2017). Fisibilitas Pilkada Serentak Tahap II Kota Pekanbaru Pasca Permendagri No 18 Tahun 2015. Jurnal Niara, 9(2), 62-74.

Zuhro, R. S. (2019). Demokrasi dan Pemilu Presiden 2019. Jurnal Penelitian Politik, 16(1), 69-81.

Google:

https://republika.co.id/page/quickcount/detail Diakses pada tanggal 28 November 2019 jam 13.20
Google:

https://id.wikipedia.org/wiki/Pemilihan_umu m_Presiden_Indonesia_2019. Diakses pada tanggal 8 Desember 2019 jam 14.10

Google: https://pakarkomunikasi.com/fungsipers-dalam-media-kontrol-sosial Diakses pada tanggal 17 Desember 2019 jam 13.00

Google:

https://m.detiknews.com/news/berita/d4446943/fakta-fakta-penting-pemilu-2019

Diakses pada tanggal 26 Desember 2019 jam 13.00 . 